\title{
The Influence of Personality Traits and Resilience on Burnout among Customer Service Representatives in a Call Centre
}

\author{
Martina Kotzét1 and Shannon Lamb ${ }^{* *}$ \\ "UFS Business School, University of the Free State, Bloemfontein 9300, \\ Free State, South Africa \\ E-mail:kotzem@ufs.ac.za \\ "Department of Industrial Psychology, University of the Free State, \\ Bloemfontein 9300, Free State, South Africa
}

\begin{abstract}
KEYWORDS Selection. Big Five Personality Traits. Stressful Work Environments. Individual Attributes. Staff Turnover

ABSTRACT The aim of the study was to identify those personality traits and resilience factors that could influence the ability of Customer Service Representatives in a call centre to manage burnout effectively. A crosssectional survey design was used and the sample consisted of 187 customer service representatives from a call centre. The Big Five Personality Structure was utilised to measure personality traits by means of the International Personality Item Pool. The Resilience Scale and the Maslach Burnout Inventory (General Survey) were used to measure resilience and burnout respectively. By means of multiple stepwise regression analysis, significant linear relationships were identified between two of the Big Five personality factors, Conscientiousness, and Agreeableness, and several of the dimensions of burnout. Resilience was found to have a significant influence on two burnout dimensions, namely Cynicism/Depersonalisation and Professional Efficacy, respectively. The results are informative in terms of its use for future selection and development purposes of customer service representatives employed in call centres.
\end{abstract}

\section{INTRODUCTION}

Competing for customers in a global economy has inspired organisations in the service industry to invent new ways of providing customer service. One of these ways is by means of call centres. As the name suggests, call centres are centralised offices assigned to telephonic contact with customers (Zapf et al. 2003), used for the purpose of sending and receiving a large volume of telephone calls (Smith 2009). Call centres are rapidly replacing the traditional highcost service channel of branch infrastructures that include face-to-face client interaction (Taylor and Bain 1999), and are becoming one of the preferred ways of delivering service in the service industry. A distinction is made between outbound and inbound call centres, depending

\footnotetext{
${ }^{1}$ Address for correspondence:

Professor Martina Kotzé

UFS Business School,

University of the Free State,

Internal post box 23

P.O. 339, Bloemfontein, 9300, Free State, South

Africa

Telephone: (+27) (51) 4013653;

Mobile: (0)83 7040848

Fax: (+27) (51) 4019397

E-mail:kotzem@ufs.ac.za
}

on the direction of contact within the call centre. In-bound operations receive and respond to incoming calls from customers while out-bound operations make calls to customers and are primarily concerned with telesales, telemarketing, or debt collection. Call centres may also provide both in-bound and out-bound services (Taylor and Bain 1999; Higgs 2004; Smith 2009). Employing millions of people in various developed and developing countries, the call centre industry is not only experiencing unprecedented growth globally, but is also playing an important role in the global economy (Deery and Kinnie 2004; Smith 2009).

The services in call centres are rendered by a special type of service employees referred to as Customer Service Representatives. With the primary task of interacting with customers by telephone, usually supported by computer systems, these employees represent the company to its customers (Zapf et al. 2003; Visser 2007). Consequently, as the main point of contact for customers accessing the organisation, these employees have a key role to play in the overall perception that customers gain of the entire organisation (Dean 2002). Depending on the nature of the business, customer service representatives may talk to between 60 and 250 clients 
per eight-hour shift. The more customers they talk to, the less time is available for each customer and the more routine these conversations may become for the customer service representative (Callaghan and Thompson 2002; Zapf et al. 2003).

Because of the nature of the work environment and the nature of the work itself, the role of customer service representatives has been regarded as one of the most stressful jobs in present-day world economy (Wallace et al. 2000; Deery et al. 2002; Holdsworth and Cartwright 2003; Lewig and Dollard 2003; Zapf et al. 2003; Malhotra and Mukherjee 2004). This is mainly as a result of the frequency and intensity of employee-client relationships (Cordes and Dougherty 1993; Maru 2002), the often conflicting demands of the company, supervisors, and customers, the repetitive nature of the work, time pressure, the low levels of job control, and the high degree of continuous performance monitoring and feedback (Grebner et al. 2003; Holman 2004; Van Dyk 2007). Furthermore, various studies conducted on the work environment of call centres indicate that many different variables inherent in the nature of call centre work have been linked to the development of employee burnout (Singh and Goolsby 1994; Taylor and Bain 1999; Wallace et al. 2000; Deery et al. 2002; Deery et al. 2004; Holman 2004). A South African study by Visser (2007) identified several critical factors contributing to burnout in customer service representatives in a call centre, including work overload, lack of career and promotion opportunities, limited skill variety, and emotional labour.

Burnout may be seen as a type of stress that develops in response to stressful working conditions over an extended period of time (Cordes and Dougherty 1993), and commonly involves physical, emotional, spiritual, intellectual, and interpersonal exhaustion (Paine 1982). As the stress continues, employees begin to lose the interest or motivation that led them to take on the job in the first place (Smith et al. 2007). Burnout may have a wide range of negative impacts on the organisation (Coetzer and Rothmann 2007) as it prevents employees from delivering quality work (Paine 1982; Rothmann 2006), leads to their having negative feelings and attitudes toward their customers, and subsequently leaves them to provide a minimal level of customer care at best (Carroll and White 1982).
Evidence is growing that burnout can also be linked to certain internal qualities of individuals (Piedmont 1993). Various researchers (Maslach 1986; Siebert 2005; Hjemdal et al. 2006) state that the internal qualities of individuals determine how people handle external sources of stress. It helps to explain why certain people will experience burnout in a certain work setting, while others will not. According to Siebert (2005), in most work environments, employees tend to be more dependent on their own ability to manage the challenges they face, and less dependent on external support. Research has also shown (Foxcroft and Roodt 2005) that the successful adjustment of employees to their work environment depends on a correct match between individuals' personal characteristics (internal qualities) and the characteristics of the work and work environment. These personal characteristics or internal qualities may include what is referred to as individual trait- and statelike qualities, respectively (Luthans et al. 2007; Youssef and Luthans 2007). Individual trait-like qualities focus on those relatively stable and fixed internal qualities of an individual, such as intelligence and personality, while individual state-like qualities refer to those internal qualities that often represent our feelings and which are relatively malleable, more changeable, and open to development, such as resilience, positive moods, optimism, and happiness (Luthans et al. 2007; Youssef and Luthans 2007). Both states and traits can be measured (Youssef and Luthans 2007) and are regarded as important variables in recruitment and selection processes during which optimum person-work environment fit is being sought (French et al. 1982).

From the literature, it is evident that several psychologists and researchers emphasise specifically two individual qualities, namely, personality (trait-like) and resilience (state-like) as feasible predictors of job burnout (Kim et al. 2000; Renck et al. 2002; Carvalho et al. 2006; Morgan and de Bruin 2010). Although, from a trait-like perspective, an individual's personality may be stable over time, it is also dynamic as it characterises individuals' unique adjustment to any given situation (Nicholas 2003). Thus, personality is thought to be related to individuals' appraisal of stressful experiences (Booth-Kewley and Vickers 1994; Brody and Ehrichman 1998; Wu and Clark 2003; Ong and Bergeman 2004; Martin 2006), and may predispose them to high- 
er or lower levels of tolerance to stress (Schultz and Schultz 1998; Ghazinour et al. 2003; Martin 2006; Jaffe-Gill et al. 2007). Therefore, personality seems to predispose individuals toward ill health and burnout or to act as a buffer against ill health and burnout (Hochwälder 2006), meaning that a stressful situation can ruin the health of one worker, and have no noticeable effect on a co-worker (Schultz and Schultz 1998).

From a state-like approach, the individual characteristic of resilience has also been frequently associated with positive thoughts and emotions, especially when the individual is experiencing a taxing event (Gustafson 1999; Strumpfer 2003; Visser 2007; Phillippe et al. 2009). Resilience is referred to as the ability and capacity of individuals to withstand situational discontinuities and to be able to adapt to new risk environments (Cleary and Malleret 2006). Research conducted by Carvalho et al. (2006) showed that individuals with higher levels of resilience are less vulnerable to burnout.

In light of the above mentioned research, it is proposed that personality and resilience may have an impact on the counteracting of burnout in customer service representatives in call centres. Taking into account that very little attention is paid to the recruitment, selection, and training processes in call centres (Townsend 2007), it is important to identify those personality traits and resilience factors that may play a role in counteracting burnout, in order to improve the person-environment fit within call centres by means of more effective selection processes. The recruitment and selection processes are a means of selecting customer service representatives who bring the skills to engage in potentially emotional labour and, subsequently, of ensuring that they are able to utilise their internal resources to manage their job stress and the avoidance of burnout more effectively (Townsend 2007). According to Higgs (2004), growth in the number and importance of call centres and attempts to manage the "people issues" have not been accompanied by a sufficient growth in research in this area of business.

\section{Objective of the Study}

The objective of this study was to identify specific personality traits and resilience factors that could influence the ability of customer ser- vice representatives of a call centre to manage burnout effectively.

\section{Theoretical Constructs}

\section{Burnout}

The signs of burnout often tend to be more mental than physical, including feelings of frustration, powerlessness, hopelessness, failure, and despair (Smith et al. 2007). Usually with the onset of burnout, the engaged, positive, and energetic relationship that employees may have with their work transforms progressively into a relationship characterised by a loss of energy, feelings of reduced commitment, increased disengagement with one's work, as well as a sense of ineffectiveness and reduced accomplishment (Maslach and Leiter 1997; Maslach et al. 2001). Burnout is generally described as consisting of three separate but interrelated constructs: emotional exhaustion, depersonalisation or cynicism, and reduced personal accomplishment (Maslach 1982; Maslach and Jackson 1986; Maslach et al. 1996; Maslach et al. 2001). Emotional exhaustion is thought to be the most important, and is the first response to develop in continuously stressful situations. It is characterised by feelings of emotional depletion, extreme tiredness, a lack of energy, and a feeling of being drained of emotional resources to cope with continuing demands (Cordes and Dougherty 1993; Schutte et al. 2000; Maslach et al. 2001). Further, it is accompanied by distress, decreased motivation, and the development of dysfunctional attitudes and behaviours at work (Maslach 1982; Maslach and Jackson 1986; Maslach et al. 1996).

When employees reach this point of extreme tiredness, they act in order to conserve and regulate their levels of energy. Subsequently, they reduce their involvement with their work, slowly withdrawing emotionally and cognitively from it. This withdrawal leads to what Maslach et al. (2001) refers to as depersonalisation or cynicism. Cynicism/depersonalisation entails the mental and emotional withdrawal from work and results in a negative, callous, or excessively detached response to various aspects of the job. The focus here is on the crisis in one's relationship with work in general and not necessarily on a crisis in one's relationship with people at work (Maslach 1982; Maslach and Jackson 1986; 
Maslach et al. 1996). Cynicism/depersonalisation can be seen as a coping response that will protect the employee from further emotional depletion. This form of coping has serious implications for companies making use of service workers to provide their services, as in the case of call centres. When service employees use cynicism/depersonalisation as a form of coping in response to high levels of emotional exhaustion, they will tend to be less responsive to and involved with the needs of their customers (Singh and Goolsby 1994; Singh 2000; Maslach et al. 2001).

In the final phase of burnout, employees compare their current levels of competence with their previous levels of competence before emotional exhaustion and cynicism/depersonalisation had set in. In this self-evaluation, they realise that they are not as competent and effective in fulfilling their job responsibilities as they used to be (Maslach 1982; Maslach and Jackson 1986; Maslach et al. 1996). Feelings of incompetence, lack of achievement, and lower productivity follow (Cordes and Dougherty 1993, Schutte et al. 2000; Maslach et al. 2001). This often leads to feelings of reduced professional efficacy (or personal accomplishment).

Burnout is a strong predictor of employee commitment and turnover intentions. Therefore, employees experiencing burnout are more likely to leave their jobs (Visser 2007). At the individual level, burnout also leads to job dissatisfaction, irritability, anxiety, a lowering of self-esteem, increased depression, the use of alcohol and drugs as well as marital and family problems (Carroll and White 1982; Paine 1982; Maslach and Jackson 1986; Singh and Goolsby 1994; Maslach and Leiter 1997; Singh 2000; Wharton 2003). As the consequences of burnout are potentially serious for the employees and for the customers (internal and external) with whom they interact, the prevention of burnout in call centres is of extreme importance.

\section{Personality}

Despite differences in the approaches defining personality, most psychologists believe that personality reflects an individual's unique and consistent pattern of thinking, feeling, and behaviour in the different contexts of their situation (Morris and Maisto 2002; Bergh 2003; Edwards 2008; Myers 2008). As there is a broad range of factors that are involved in shaping personality, including hereditary factors, sociocultural determinants, unconscious mechanisms, and cognitive processes (O'Neil 2006), each personality has its own configuration of aspects that gives the person distinctiveness in all facets. One of the most frequently-cited explanations of personality was proposed by Allport (1937: 48), who suggested that personality is "the dynamic organisation within the individual of those psychophysical systems that determine his unique adjustments to his environment". Thus, personality focuses on individual differences that drive people to behave in a certain manner, as well as how these individual dispositions interact with different situations to influence behaviour.

For the purposes of this study, a five-factor structure of personality, referred to as the Big Five Personality was used (Tupes and Christal 1961; Norman 1963, 1967; Costa and McCrae 1987; Goldberg 1990). This five-factor model of personality presents a structure of personality that is best described by five global domains or factors that characterise individual differences. These five broad traits constitute a complete description of an individual's personality (McCrae and Costa 2006), and are labeled: Extraversion, Agreeableness, Conscientiousness, Neuroticism, and Openness to Experience (Digman 1990). Extraversion includes the outward turning of psychic energy toward the external world (De Raad 2000). Individuals who score high on extraversion are regarded as sociable, active, talkative, fun-loving, and optimistic (Edwards 1998), whilst individuals scoring low on extraversion tend to be more reserved and quiet (Costa and Widiger 1994; Edwards 1998). Agreeableness is the trait that is most concerned with interpersonal relationships (De Raad 2000), and refers to the kinds of interactions a person prefers (Costa and Widiger 1994). Individuals who score high on agreeableness are pleasant and easy to be around as they tend to accommodate the wishes and needs of others, and have strong social relationships (Pawlik-Kienlen 2007). On the other hand, individuals who score low on agreeableness tend to be rude, irritable, uncooperative, and suspicious, tending to cater for their own needs (Edwards 1998). Conscientiousness represents the drive to accomplish something, including features such as high levels of thoughtfulness, good impulse control, and goal- 
directed behaviour (De Raad 2000). Pawlik-Kienlen (2007) states that conscientious individuals are organised, disciplined, dedicated and loyal, especially at work, while individuals scoring low on conscientiousness seem to be aimless, negligent, careless, and unreliable (Edwards 1998).

Neuroticism refers to a continual level of emotional adjustment and instability (Costa and Widiger 1994). Individuals who score high on the neuroticism trait tend to experience emotional instability, anxiety, moodiness, and irritability (Pawlik-Kienlen 2007), and are inclined to be worrying, insecure, and nervous (Edwards 1998). Low scores on neuroticism indicate a more unemotional, relaxed, calm, and secure individual. Openness to experience involves actively seeking and appreciating new experiences (Costa and Widiger 1994), and has also been referred to as imagination or intellect (Goldberg et al. 2006). Individuals who score high on openness to experience tend to be curious, seek new and unfamiliar experiences, have a broad range of interests, and are easily bored (Edwards 1998). They also seem to love adventure, and are insightful and imaginative, not being afraid of taking risks (Pawlik-Kienlen 2007). Individuals with lower scores on openness to experience may be more narrow-minded, conventional, unimaginative, practical, preferring familiar territory (Edwards 1998).

The practical value of the Big Five model is that it allows the domain of personality to be represented widely and systematically (Briggs 1992), providing a practical solution to the question of personality structure (Digman 1990). McCrae and John (1992) suggest three advantages of using the five-factor model of personality: (1) it integrates a wide array of personality constructs, allowing researchers across different fields of study to communicate easily; (2) it is comprehensive, providing a means of studying relations between personality and other phenomena; and (3) it is efficient, as it offers at least a global description of personality. Furthermore, there is a large quantity of research evidence that suggests that the model can be applied successfully in different cultures (Borkenau and Ostendorf 1990; Trull and Deary 1997; Tsaousis 1999).

The role of personality as a causative agent in burnout has recently received increased attention (Kim et al. 2000; Renck et al. 2002), and various studies have been conducted on the relationship between personality and burnout (Deary et al. 1996; Zellars et al. 2000; LePine et al. 2004; Bakker et al. 2006; Langelaan et. al. 2006; Dahlin et al. 2007; Gan et al. 2007; Kokkinos 2007; Jensen 2008).

\section{Resilience in the Workplace}

Although various definitions of resilience have been proposed (Hjemdal et al. 2006), resilience is generally described as an ability of individuals (a) to cope and adapt successfully to situational discontinuities and risk environments (Mandleco and Peery 2000; Johnson and Howard 2002; Miller 2003; Ong and Bergeman 2004; Griffith 2007; Luthens et al. 2007), (b) to overcome or "bounce back" from disadvantageous circumstances, risk, and adversity (Johnson and Howard 2002; Johnson and Wiechelt 2004; Tusaie and Dyer 2004; Arehart-Treichel 2005; Fergus and Zimmerman 2005; Youssef and Luthans 2007), and (c) to draw on inner strengths, skills, and support (Johnson and Wiechelt 2004) in order to maintain psychological well-being and health despite risks, threats, and adversity (Johnson and Howard 2002; Fergus and Zimmerman 2005). Arehart-Treichel (2005) defines the essence of resilience as the ability to rebound from stress effectively and to attain good functioning, despite difficulty. Thus, resilient individuals are able to find personal meaning in obstacles they experience in their work environment, and are able to deal with any accompanying emotion (Lew 2001). Several researchers emphasise the notion that resilient people not only expect and maintain good and positive outcomes (Siebert 2005; Hjemdal et al. 2006; Kruger and Prinsloo 2008), but also tend to regard life's challenges as opportunities for pro-active learning, growth, and development (Strumpfer 2003; O'Rourke 2004; Theron 2004; Youssef and Luthans 2007; Kruger and Prinsloo 2008).

Although research on resilience has been limited mainly to clinical and positive psychology (Luthans et al. 2008), preliminary research has begun to examine the role of resilience in the workplace (Grotberg 2003; Visser 2007; Luthans et al. 2008). Within the workplace, resilience can be seen as the ability to accept and adapt to organisational changes, being comfortable with new and different people, being willing to take risks, and displaying self-confidence (London 1993). Furthermore, it includes the ability to re- 
cuperate and grow as a result of environmental pressures and barriers in the domain of work (Lew 2001), being able to gain control quickly with an angry person, divert personal attacks, remain immune to negative talk, and cope well with dysfunctional people (Siebert 2005). Siebert (2005) states that resiliency is an essential skill in every job sector, including corporations, small businesses, public agencies, professional services, and the self-employed.

Wagnild and Young (1993) define resilience as a characteristic that moderates the negative effects of stress, and promotes adjustment to circumstances. These authors identified two dimensions of resilience: Personal Competence and Acceptance of Self and Life. Higher levels of personal competence reflect characteristics such as self reliance, determination, resourcefulness, and independence, while acceptance of self and life reflects a sense of peace despite adverse conditions, accompanied by adaptability and flexibility (Wagnild and Young 1993). Siebert (2005) states that resilient people's "ability to engage in positivity and/or negativity, remains unactivated until a situation brings out either or both dimensions" (Siebert 2005: 200).

As customer service representatives in call centres represent the company to customers on a daily basis, it seems imperative that call centres should ensure the successful adjustment of their employees to the call centre work environment in order to prevent burnout and the subsequent consequences thereof. As the call centre work environment has been shown to have a significant influence on the development of burnout, it is essential to identify those individual qualities that counteract the likelihood of customer service representatives possibly falling victim to burnout, and to include the measurement of these qualities in the selection process so as to ensure a better person-environment fit. Akroyd et al. (2006) state clearly the importance of focusing recruitment and selection strategies not only on technical ability, but also on the personal characteristics of potential employees in call centres.

\section{RESEARCH METHODOLOGY}

In order to execute the research, a cross-sectional research design was used. Based on the aim of the study, the following hypotheses were formulated:
Null Hypothesis $\left(\boldsymbol{H}_{0}\right)$ : There is no linear relationship between the scores on personality traits and burnout among employees at a call centre in South Africa.

Alternative Hypothesis $\left(\boldsymbol{H}_{1}\right)$ : There is a linear relationship between the scores on personality traits and burnout among employees at a call centre in South Africa.

Null Hypothesis $\left(H_{0}\right)$ : There is no linear relationship between the scores on resilience and burnout among employees at a call centre in South Africa.

Alternative Hypothesis $\left(\boldsymbol{H}_{1}\right)$ : There is a linear relationship between the scores on resilience and burnout among employees at a call centre in South Africa.

\section{Research Participants}

Non-probability sampling and, more specifically, accidental sampling was used in a call centre in South Africa. A total of 187 employees in the call centre were involved in the study. The call centre involved is an out-bound, debt-collecting call centre, with clients in South Africa and its neighbouring states. The majority of the respondents are black $(97.5 \%)$, female $(79.7 \%)$, single or widowed $(66.5 \%)$, use South Sotho as their home language (60.45), are between 21 and 25 years of age $(59.9 \%)$, have acquired a grade 12 qualification $(52.8 \%)$, and have served in the call centre for two years or less $(92.8 \%)$.

\section{Measuring Instruments}

Three questionnaires were used in the study, namely, the International Personality Item Pool (IPIP); the Resilience Scale; and the Maslach Burnout Inventory (General Survey).

\section{The International Personality Item Pool}

The International Personality Item Pool consists of 50 questions. Respondents were asked to rate themselves on a 5-point Likert scale, with 1 being very inaccurate, and 5 very accurate. The questionnaire measures all five of the Big Five Personality Factors, namely Extroversion, Neuroticism, Agreeableness, Conscientiousness, and Openness to Experience (Goldberg et al. 2006). The coefficient alpha for the International Personality Item Pool was found to be .84 (Goldberg et al. 2006), and is regarded as ade- 
quate (Murray et al. 2009). Support for convergent and discriminant validity was found through studies conducted by Lim and Ployhart (2006) and Buchanan (2001).

\section{The Resilience Scale}

The purpose of the Resilience Scale (Wagnild and Young 1993) is to measure the degree of individual resilience by means of two dimensions of resilience - Personal Competence and Acceptance of Self and Life. Higher levels of personal competence reflect characteristics such as self reliance, determination, resourcefulness, and independence, while acceptance of self and life reflects a sense of peace despite adverse conditions, accompanied by adaptability and flexibility (Wagnild and Young 1993). The Resilience Scale is a 25-item scale. Respondents are asked to rate the degree to which they agree or disagree with each item. All questions are scored on a 7-point scale ranging from 1 ("disagree") to 7 ("agree") with higher scores reflecting higher resilience (Wagnild and Young 1993).

The internal consistency reliability for the questionnaire was found to be .89 in various samples, and the coefficient alpha .91, which is considered satisfactory (Wagnild and Young 1993). Construct and concurrent validity has also been supported in various studies (Wagnild and Young 1993). Neill and Dias (2001) examined the Resilience Scale and found the items' face validity as satisfactory.

\section{Maslach Burnout Inventory (General Survey)}

The Maslach Burnout Inventory (General Survey) is a 22-item instrument that measures the following aspects of professional burnout: emotional exhaustion, which is the reduction of emotional energy or mental fatigue; cynicism/ depersonalisation, which involves a distant attitude towards work, and, lastly, professional efficiency, which is similar to personal accomplishment, which emphasises the feeling of having a beneficial impact on people (Maslach et al. 1996). The reliability of the Maslach Burnout Inventory has been proven to be satisfactory in various South African studies (van den Berg et al. 2006). The reliability coefficients were found to be .90 for emotional exhaustion, .79 for cynicism/depersonalisation, and .71 for professional efficacy (personal accomplishment) (Maslach et al. 1996). The validity of the Maslach Burnout Inventory is well established (Brenninkmeyer et al. 2000), and the convergent and discriminant validity has been demonstrated in several ways (Maslach et al. 1996).

\section{Research Procedure}

The researcher and managers of the call centre were directly involved with the distribution of the questionnaires on site. The questionnaires were completed in groups under supervision, and were collected immediately after the customer service representatives had completed them. Instructions were given verbally, as well as in a written format. All customer service representatives were told not to write their name, numbers, or any identifying information on the questionnaires. When the completed questionnaires were collected, participants were asked to place their questionnaires in a box, further minimising the identification of questionnaires.

\section{Statistical Analysis}

Both descriptive and inferential statistics were applied in the analysis of the data. Multiple stepwise regression analysis was used to determine the impact of the Big Five Personality attributes and resilience as potential predictors of job burnout.

\section{RESULTS}

The aim of the study was to examine whether specific personality and resilience factors have an influence on burnout in customer service representatives in a call centre in South Africa. The levels of burnout experienced by the Customer Service Representatives are outlined in Table 1. Tables 2 to 6 indicate the impact of the independent variables, namely the Big Five Personality traits (Extraversion, Agreeableness, Conscientiousness, Neuroticism, and Openness to Experience) and the two dimensions of resilience (Personal Competence and Acceptance of Self and Life) on the components of burnout, namely Emotional Exhaustion, Cynicism/Depersonalisation and Professional Efficacy (Personal Accomplishment).

From Table 1, it is evident that the means regarding emotional exhaustion, cynicism/depersonalisation, and professional efficacy (per- 
sonal accomplishment) of customer service representatives of the call centre were 24.98, 26.16, and 29.70, respectively. These means indicate an average level of emotional exhaustion, a high level of cynicism/depersonalisation, and a low level of professional efficacy (personal accomplishment).

Table 1: Arithmetic means, standard deviation, skewness and kurtosis of customer service representatives of the call centre regarding burnout $(\mathrm{N}=187)$

\begin{tabular}{lllll}
\hline $\begin{array}{l}\text { Dimensions } \\
\text { of burnout }\end{array}$ & $\begin{array}{l}\text { Mean } \\
\text { Statis- } \\
\text { tics }\end{array}$ & $\begin{array}{l}\text { Std. } \\
\text { devia- } \\
\text { tion } \\
\text { Stati- } \\
\text { stic }\end{array}$ & $\begin{array}{l}\text { Skess } \\
\text { Statis- } \\
\text { tics }\end{array}$ & $\begin{array}{l}\text { Kurtosis } \\
\text { Statis- }\end{array}$ \\
\hline $\begin{array}{l}\text { Emotional } \\
\quad \text { Exhaustion }\end{array}$ & 24.98 & 7.71 & -0.11 & 0.34 \\
$\begin{array}{l}\text { Depersonalisation } \\
\begin{array}{l}\text { Personal Accom- } \\
\text { plishment }\end{array}\end{array}$ & 26.16 & 8.02 & -0.31 & 0.07 \\
$\quad$ & 29.70 & 7.10 & -0.19 & 1.12 \\
\hline
\end{tabular}

From Table 2, it is evident that conscientiousness was the only significant predictor $(\mathrm{p}<0.01)$ of emotional exhaustion of customer service representatives with regard to the Big Five personality structure. The results also showed that neither dimensions of resilience were significant predictors of emotional exhaustion.

Table 2: The prediction of emotional exhaustion of customer service representatives of the call centre by means of the Big Five Personality traits and resilience $(\mathrm{N}=187)$

\begin{tabular}{lccccc}
\hline Step Variable & $\begin{array}{c}\text { Standard } \\
\text { error of } \\
\text { the } \\
\text { estimate }\end{array}$ & $\begin{array}{c}\text { Mul- } \\
\text { tiple }\end{array}$ & $\begin{array}{c}R \\
\text { squ- } \\
\text { are }\end{array}$ & $\begin{array}{c}F \\
\text { va- } \\
\text { lue }\end{array}$ & $\begin{array}{c}p \\
\text { lue } \\
\text { lue }\end{array}$ \\
\hline $1 \quad \begin{array}{c}\text { Conscien- } \\
\text { tiousness }\end{array}$ & 7.45 & 0.27 & 0.08 & 15.56 & $.00^{* * *}$ \\
& & & & & \\
\hline $\mathrm{p}<0.05^{* *} \mathrm{p}<0.01$ & & & & &
\end{tabular}

It is evident from Table 3 that conscientiousness was also the only significant predictor $(\mathrm{p}<0.01)$ of cynicism/depersonalisation of customer service representatives with regard to the Big Five personality structure.

Table 4 shows that a dimension of resilience, namely acceptance of self and life, was a significant predictor $(\mathrm{p}<0.01)$ of cynicism/depersonalisation.
Table 3: The prediction of cynicism/depersonalisation of customer service representatives of the call centre by means of the Big Five Personality traits and resilience $(\mathrm{N}=187)$

\begin{tabular}{lllllll}
\hline Step Variable & $\begin{array}{l}\text { Standard } \\
\text { error of } \\
\text { the } \\
\text { estimate }\end{array}$ & $\begin{array}{c}\text { Mul- } \\
\text { tiple }\end{array}$ & $\begin{array}{c}R \\
\text { squ- va- } \\
\text { are }\end{array}$ & $\begin{array}{l}p \\
\text { lue }\end{array}$ & $\begin{array}{l}\text { va- } \\
\text { lue }\end{array}$ \\
\hline 1 & $\begin{array}{c}\text { Conscien- } \\
\text { tiousness }\end{array}$ & 7.53 & 0.35 & 0.13 & 27.28 & $.00^{*}$
\end{tabular}

* $\mathrm{p}<0.05 \quad$ *** $\mathrm{p}<0.01$

Table 4: The prediction of cynicism/depersonalisation of customer service representatives of the call centre by means of the dimensions of resilience $(\mathrm{N}=187)$

\begin{tabular}{lccllll} 
Step & Variable & $\begin{array}{l}\text { Standard } \\
\text { error of } \\
\text { the } \\
\text { estimate }\end{array}$ & $\begin{array}{l}\text { Mul- } \\
\text { tiple }\end{array}$ & $\begin{array}{l}R \\
\text { squ- } \\
\text { are }\end{array}$ & $\begin{array}{l}F \\
\text { va- } \\
\text { lue }\end{array}$ & $\begin{array}{l}p \\
\text { va- } \\
\text { lue }\end{array}$ \\
\hline $1 \quad$ & $\begin{array}{c}\text { Conscien- } \\
\text { tiousness }\end{array}$ & 7.72 & 0.27 & 0.08 & 25.07 & $.00^{*}$ \\
\hline
\end{tabular}

${ }^{*} \mathrm{p}<0.05 \quad{ }^{* *} \mathrm{p}<0.01$

Table 5: The prediction of professional efficacy (personal accomplishment) of customer service representatives of the call centre by means of Big Five Personality traits $(\mathrm{N}=187)$

\begin{tabular}{lllllll}
\hline Step & Variable & $\begin{array}{l}\text { Standard } \\
\text { error of } \\
\text { the } \\
\text { estimate }\end{array}$ & $\begin{array}{c}\text { Mul- } \\
\text { tiple }\end{array}$ & $\begin{array}{c}R \\
\text { squ- va- } \\
\text { are }\end{array}$ & $\begin{array}{c}p \\
\text { lue }\end{array}$ & $\begin{array}{l}\text { va- } \\
\text { lue }\end{array}$ \\
\hline 1 & $\begin{array}{c}\text { Conscien- } \\
\text { tiousness }\end{array}$ & 6.96 & 0.22 & 0.05 & $9.31 .003^{*}$ \\
2 & $\begin{array}{c}\text { Agreeab- } \\
\text { leness }\end{array}$ & 6.89 & 0.26 & 0.07 & $7.13 .001^{*}$ \\
\hline
\end{tabular}

${ }^{*} \mathrm{p}<0.05^{* *} \mathrm{p}<0.01$

Table 6: The prediction of professional efficacy (personal accomplishment) of customer service representatives of the call centre by means of resilience $(\mathrm{N}=187)$

\begin{tabular}{|c|c|c|c|c|c|c|}
\hline Step & Variable & $\begin{array}{l}\text { Standard } \\
\text { error of } \\
\text { the } \\
\text { estimate }\end{array}$ & $\begin{array}{c}\text { Mul- } \\
\text { tiple } \\
R\end{array}$ & $\begin{array}{l}R \\
\text { squ- } \\
\text { are }\end{array}$ & $\begin{array}{c}F \\
\text { va- } \\
\text { lue }\end{array}$ & $\begin{array}{l}p \\
\text { va- } \\
\text { lue }\end{array}$ \\
\hline 1 & $\begin{array}{l}\text { Personal } \\
\text { competence }\end{array}$ & $e^{6.84}$ & 0.2 & 0.04 & 7.87 & .006 \\
\hline
\end{tabular}

It is evident from Table 5 that both conscientiousness and agreeableness were significant predictors $(\mathrm{p}<0.01)$ of professional efficacy (personal accomplishment). 
From Table 6, it is evident that a dimension of resilience, namely, personal competence, was a significant predictor $(\mathrm{p}<0.01)$ of professional efficacy (personal accomplishment).

From the above it seems that there is a linear relationship between the scores on personality traits and burnout among employees at the call centre, as well as a linear relationship between the scores on resilience and burnout among employees in the call centre. Therefore, both of the null hypotheses were rejected. These results are discussed critically in the section below.

\section{DISCUSSION}

From these results, it is evident that customer service representatives of this call centre experienced feelings of emotional depletion, tiredness, and a lack of energy (emotional exhaustion). They also showed high levels of mental and emotional withdrawal from their work, resulting not only in reduced involvement in their work (cynicism/depersonalisation), but also in feelings of incompetence and a lack of achievement (professional efficacy).

Since cynicism/depersonalisation is a coping response in order to protect employees from further emotional depletion (Maslach 1982), it may be deduced that the customer service representatives started to withdraw emotionally and cognitively from their work in order to protect themselves from further emotional depletion (Singh 2000; Maslach et al. 2001). Low levels of professional efficacy (personal accomplishment) were also experienced, and may be indicative of customer service representatives already moving into the final phase of burnout (Maslach 1982; Maslach and Jackson 1986; Maslach et al. 1996). What was both interesting and alarming is that approximately $93 \%$ of the sample had served in the call centre for only two years or less, but were already showing these high levels of burnout, especially in terms of cynicism/ depersonalisation. Since it is clear from the literature that disengaged employees are unlikely to provide the service quality necessary for the high levels of customer satisfaction upon which commercial success increasingly depends, these results are even more alarming for this specific call centre.

Conscientiousness was the only significant predictor of emotional exhaustion of customer service representatives with regard to the Big Five personality structure. These results thus indicate that customer service representatives who are goal-directed, well- organised, disciplined, and have high levels of thoughtfulness at work, tend to be less emotionally exhausted. This is in line with research done both in South Africa and internationally (Kim et al. 2000; Storm and Rothmann 2003; LePine et al. 2004). A study by Storm and Rothmann (2003) showed that higher scores on conscientiousness is associated with lower levels of emotional exhaustion, as well as with constructive coping strategies and the positive reinterpretation of stressful situations. Kim et al. (2000) also found conscientiousness to be one of the personality traits that influence how an individual handles stressful work situations, and identified it as a significant predictor of burnout. The other personality traits, namely extraversion, neuroticism, openness to experience, and agreeableness, as well as resilience did not appear to be significant predictors of emotional exhaustion in this study. This is in contrast with the results of previous research where it was found that emotional exhaustion is predicted by neuroticism (Bakker et al. 2006; Kokkinos 2007; Jensen 2008), agreeableness (Piedmont 1993; Zeng and Chi 2007), and extraversion (Eastburg et al. 1994; Francis et al. 2004). Carvalho et al. (2006) found that individuals with higher levels of resilience appear to be less emotionally exhausted than individuals with lower levels of resilience.

The results also showed that cynicism/depersonalisation is predicted by conscientiousness. This finding support previous research where conscientiousness was identified as a significant predictor of cynicism/depersonalisation (Deary et al. 1996). Research done in South Africa by Storm and Rothmann (2003) showed that higher levels of conscientiousness are associated with lower levels of cynicism/depersonalisation, while Korotkov (2008) also found that conscientiousness acts as a buffer in the stressto-distress relationship. However, in contrast with the results of this study, several other studies also found openness to experience (Bakker et al. 2006; Kokkinos 2007), extraversion (Zellers et al. 2000; Francis et al. 2004) and neuroticism (Le Pine et al. 2004; Langelaan et al. 2006) as significant predictors of cynicism/ depersonalisation.

Conscientiousness and agreeableness were also significant predictors of professional effi- 
cacy (personal accomplishment). Agreeableness is the trait that is most concerned with interpersonal relationships (De Raad 2000), and refers to an individual's capacity for sympathy, trust, altruism, and cooperation (McCrae and Costa 1989). This is in line with previous research done internationally and in South Africa which showed that agreeableness (Bakker et al. 2006) and conscientiousness (Deary et al. 1996; Storm and Rothmann 2003) are associated with higher levels of personal efficacy (personal accomplishment). Thus, it seems that customer service representatives who are goal-oriented, strongwilled, and determined (conscientiousness), and who are likely to be eager to assist others, in a selfless, empathetic manner, with the basic belief that others will be helpful in return (agreeableness), feel more competent and effective in fulfilling their job responsibilities (personal efficacy). Other researchers, in contrast with this study, also found professional efficacy to be predicted by neuroticism (Miner 2007) and extraversion (Bakker et al. 2006; Miner 2007).

With regard to resilience, the dimension of acceptance of self was a significant predictor of cynicism/depersonalisation, meaning that customer service Representatives who maintain a sense of peace, while adapting and staying flexible despite adverse conditions (Wagnild and Young 1993), have a better chance of staying cognitively and emotionally involved with their work. On the other hand, personal competence, the second dimension of resilience, was also shown to be a significant predictor of professional efficacy (personal accomplishment), indicating that characteristics such as self reliance, determination, resourcefulness, and independence may lead to feelings of competence and achievement, and therefore may reduce the possibility of experiencing burnout. These results are in line with studies conducted by Scott (2007) and Philippe et al. (2009), who found that individuals who score high on resilience are better able to adapt to adversity without lasting difficulties, and are more inclined to have positive emotions when experiencing a taxing event, while less resilient people have a harder time with stress and life's changes.

In summary, one Big Five Personality trait, namely conscientiousness, was found to be a significant predictor of all three dimensions of burnout, including emotional exhaustion, cyni- cism/depersonalisation, and professional efficacy. Interestingly enough, research done by Higgs (2004) and Skyrme et al. (2005) in call centres in the United Kingdom and the United States respectively, also showed highly significant relationships between conscientiousness and successful performance outcomes. Furthermore, the current study showed that agreeableness was a significant predictor of professional efficacy (personal accomplishment). Thus, professional efficacy (personal accomplishment) was predicted by both conscientiousness and agreeableness. Resilience, on the other hand, was a predictor of both cynicism/depersonalisation and professional efficacy (personal accomplishment). More specifically, the dimension, acceptance of self and life, was found to be a significant predictor of cynicism/depersonalisation, while personal competence was a significant predictor of professional efficacy.

Although some of the results were supported by previous studies, the majority of the results were not consistent with previous findings relating to Big Five Personality traits, or to job burnout in studies executed in various types of workplace. This may be due not only to the specific and unique circumstances within the work environment of a call centre, but also to the nature of the sample. Since approximately $80 \%$ of the participants in this study are female and approximately $60 \%$ are between the age of 21 and 25 years old, the demographic nature of the sample might have had an effect on the results. For example, a study by Bhattacharya and Bhattacharya (2007) involving a group of employees in different call centres in Kolkata City, India, showed that there were significant differences in personality traits, such as openness to change, emotional stability, diplomacy, and selfreliance between male and female employees. Similarly, Higgs (2004) found differences between age and gender groups in terms of performance of agents in call centres in the United Kingdom. A study by Belt et al. (2002) indicated that females are recruited specifically by call centre employers in part because they are deemed to "naturally" possess the kinds of communication skills required in call centres, and that they expect women to perform emotional labour over the phone, using their femininity to secure competitive advantage. Thus, it may be that the demographic nature of the sample may have influenced the results. 


\section{CONCLUSION}

The aim of the study was to examine whether specific personality and resilience factors have an influence on burnout in customer service representatives in a call centre in South Africa. The study reported has demonstrated some strong linkages between the Big Five Personality traits and resilience on the one hand, and burnout in a call centre, on the other.

Recruitment and selection processes are means of selecting customer service representatives who not only bring the skills to potentially engage in call centre work environments that demand high levels of emotional labour, but who are also continually energetic and enthusiastic, and have the stamina and survival skills to get through 60-250 repetitive calls in a day while avoiding burnout. Although the results of this study cannot be generalised, the results are informative in terms of their use for future selection and development purposes of customer service representatives in call centres.

\section{RECOMMENDATIONS}

Since this study has identified personality attributes and resilience dimensions that contribute to the effective personal management of burnout in customer service representatives within a call centre, the results can be used to create a better match between internal individual qualities of customer service representatives and the demands of the call centre work environment. This may enable recruitment and personnel agencies involved in the recruitment and selection of customer service representatives for call centres, as well as the human resource departments and management personnel within call centres, to assess more effectively a potential job candidate's suitability to the demands of the work environment and to discern better between candidates more or less susceptible to job burnout. The recruitment and selection processes should be used to identify, through experience and predisposition, the existence of social competencies functional to service interactions.

Since the development of negative outcomes, such as burnout, can be reduced or prevented by means of protective mechanisms, which can be located both externally (extrinsic) and internally (intrinsic) to the individual, human resource personnel, equipped with an un- derstanding of the potentially cumulative effects of burnout and its adverse outcomes, can also develop skills and tools to assist customer service representatives in handling their stresses and strains more effectively on a day-to-day basis, in order to avoid burnout. Resilience can be developed through short training interventions designed to develop positive psychological internal capacities and to avoid proactively risky, potentially adverse events, such as not meeting critical deadlines. In affecting the perception of influence in building resiliency, cognitive processes can also be employed to frame setbacks in terms of their impact, the individual's level of control in the situation, and the different options available to the individual. External protective factors, in the form of resources, can be provided by the management of call centres by creating a supportive work environment where resilience can be enhanced through the practice of caring relationships.

In terms of future research, a replication of this study with a larger sample of call centres, representing a more diverse range of business contexts as well as of demographics in terms of customer service representatives, would be valuable. Also, a broader range of individual qualities, apart from personality traits and resilience, could be included in future studies. Because of the high levels of burnout in call centres, future studies could also focus on how call centre organisations can create a work environment where levels of job stress and burnout of customer service representatives can be reduced.

\section{REFERENCES}

Akroyd K, Gordon-Dseagu V, Fairhurst P 2006. Wellbeing and Call Centres. Institute for Employment Studies. Brighton: University of Sussex Campus.

Allport GW 1937. Personality: A Psychological Interpretation. New York: Holt, Rinehart and Winston.

Arehart-Treichel J 2005. Resilience Shown in Youth Protects Against Adult Stress. Psychiatr News, 40(17): 14. From< http://pn.psychiatryonline. org/cgi/content/full/40/17/14> (Retrieved March 14, 2008).

Bakker AB, Van der Zee KI, Lewig KA, Dollard MF 2006. The relationship between the big five personality factors and burnout: A study among volunteer counsellors. J Soc Psychol, 146(1): 3150 .

Belt V, Richardson R, Webster J 2002. Women social skill and interactive service work in telephone 
call centres. New Tech Work Employ, 17(1): 2034.

Bergh ZC 2003. The foundations of personality. In: ZC Bergh, AL Theron (Eds.): Psychology in the Work Context. $2^{\text {nd }}$ Edition. Cape Town: Oxford University Press Southern Africa.

Bhattacharya S, Bhattacharya T 2007. Personality patterns of employees of call centres. J Indian Acad Appl Psychol, 33(2): 295-300.

Booth-Kewley S, Vickers RR 1994. Associations between major domains of personality and health behaviour. J Pers, 62: 281-298.

Borkenau P Ostendorf F 1990. Comparing exploratory and confirmatory factor analysis: A study of the 5-Factor Model of personality. Pers Indiv Differ, 11: 515-524.

Brennikmeyer V, Van Yperen NW, Buunk BP 2000. Burnout and depression are not identical twins: Is decline of superiority a distinguishing feature? Pers Indiv Differ, 30(5): 873-880.

Briggs SR 1992. Assessing the Five-Factor Model of personality description. J Pers, 60: 253-293.

Brody N Ehrichman H 1998. Personality Psychology: The Science of Individuality. Upper Saddle River, NJ: Prentice Hall.

Buchanan T 2001. Online Implementation of an IPIP Five Factor Personality Inventory. From< http:/ /users.wmin.ac.uk/ buchant/wwwfi/ introduction.html\#Buchanan,\% 20T.,\% 20Goldberg, \%2 0L.\%20R.,\%20 \&\%20 Johnson,\% 20J.\%20A> (Retrieved December 02, 2009).

Callaghan G, Thompson P 2002. We recruit attitude: The selection and shaping of routine call centre labour. J Manag Stud, 39(2): 233-254.

Carrol JFX, White WL 1982. Theory building: Integrating individual and environmental factors within an ecological framework. In: WS Paine (Ed.): Job Stress and Burnout: Research, Theory and Intervention Perspectives. United States of America: SAGE Publications Ltd, pp. 41-60.

Carvalho MVA, Calvo FB, Martin HL, Campos RF, Castillo CI 2006. Resilience and the burnout-engagement Model in Formal Caregivers of the Elderly. Psicothema, 18(4): 791-796. From< http:/ /www.ncbi.nlm.nih.gov/pubmed/17296119> (Retrieved November 23, 2009).

Cleary S, Malleret T 2006. Resilience to Risk: Business Success in Turbulent Times. Cape Town: Human and Rousseau.

Coetzer WJ, Rothmann S 2007. A psychometric evaluation of measures of affective well-being in an insurance company. S Afr J Indus Psychol, 3(2): 7-15.

Cordes CL, Dougherty TW 1993. A review and an integration of research on job burnout. Acad Manag Rev, 18: 621-656.

Costa PT, McCrae RR 1987. Validation of the Five Factor Model of personality across instruments and observers. J Pers Soc Psychol, 52: 81-90.

Costa PT, Widiger TA 1994. Introduction: Personality disorders and the Five-factor Model of personality. In: PT Costaand, TA Widiger (Eds.): Personality Disorders and the Five-factor Model of Personality. Washington: American Psychological Association, pp. 1-10.
Dahlin N, Joneborg N, Runeson B 2007. Performancebased self-esteem and burnout in a cross-sectional study of medical students. Med Teach, 29: 4348.

De Raad B 2000. The Big Five Personality Factors: A Psycholexical Approach to Personality. Germany: Hogrefe and Huber Publishers.

Dean AM 2002. Service Quality in call centres: Implications for customer loyalty. Manag Serv Qual, 12(6): 414-423.

Deary IJ, Blenkin H, Agius RM, Endler NS, Zealley H, Wood R 1996. Models of job-related stress and personal achievement among consultant doctors. Br J Psychol, 87: 3-29.

Deery S, Iverson R, Walsh J 2002. Work relationships in telephone call centres: Understanding emotional exhaustion and employee withdrawal. $J$ Manag Stud, 39: 471-496.

Deery S, Iverson R, Walsh J 2004. The effect of customer service encounters on job satisfaction and emotional exhaustion. In: S Deery, N Kinnie (Eds.): Call Centres and Human Resource Management: A Cross-national Perspective. New York: Palgrave Macmillan, pp. 201-221.

Deery S, Kinnie N 2004. Introduction: The nature and management of call centre work. In: S Deery, $\mathrm{N}$ Kinnie (Eds.): Call Centres and Human Resource Management: A Cross-national Perspective. New York: Palgrave Macmillan, pp. 1-21.

Digman JM 1990. Personality structure: Emergence of the Five-factor Model. Ann Rev Psychol, 41: 417-440.

Eastburg MC, Williamson M, Gorsuch R, Ridley C 1994. Social support, personality and burnout in nurses. J Appl Soc Psychol, 24: 1233-1250.

Edwards D 1998. Personality. In: DA Louw, DJA Edwards (Eds.): Psychology: An Introduction for Students in Southern Africa. $2^{\text {nd }}$ Edition. Rivonia: Heinemann, pp. 541-603.

Edwards DJA 2008. Personality. In: DA Louw, DJA Edwards (Eds.): Psychology: An Introduction for Students in Southern Africa. $2^{\text {nd }}$ Edition. Johannesburg: Heinemann, pp. 542-604.

Fergus S, Zimmerman MA 2005. Adolescent resilience: A framework for understanding healthy development in the face of risk. Ann Rev Publ Health, 26: $399-419$

Foxcroft C, Roodt G 2005. An Introduction to Psychological Assessment in the South African Context. $2^{\text {nd }}$ Edition. Cape Town: Oxford University Press.

Francis LJ, Louden SH, Rutledge CJF 2004. Burnout among Roman Catholic parochial clergy in England and Wales: Myth or reality? Rev Relig Res, 46: 5-19.

French JRP, Caplan RD, Harrison R 1982. The Mechanisms of Job Stress and Strain. United States of America: John Wiley and Sons Ltd.

Gan Y, Shang J, Zhang Y 2007. Coping flexibility and locus of control as predictors of burnout among Chinese college students. Soc Behav Pers, 35(8): 1087-1098

Ghazinour M, Richter J, Emami H, Eisemann M 2003. Do parental rearing and personality characteristics have a buffering effect against psychopathological manifestations among Iranian refugees in Sweden? Nord J Psychiatry, 57(6): 419-428. 
Goldberg LR 1990. An alternative 'description of personality': The Big Five Factor structure. J Pers Soc Psychol, 59: 1216-1229.

Goldberg LR, Johnson JA, Eber HW, Hogan R, Ashton MC, Cloninger CR, Gough HG 2006. The International Personality Item Pool and the Future of Public-Domain Personality Measures. From< http://www.personal.psu.edu/faculty/j/5/j5j/papers/IPIP2006.pdf> (Retrieved November 06, 2008)

Grebner S, Semmer NK, Lo Faso L, Gut S, Kalin W, Elfering A 2003. Working conditions, well-being and job-related attitudes among call centre agents. Eur J Work Organ Psychol, 12(4): 341-365.

Griffith D 2007. A New Year's Resolution for Your Emotional Health. From< www.healthatoz.com> (Retrieved March 22, 2007).

Grotberg EH 2003. What is resilience? how do you promote it? how do you use it? In: EH Grotberg (Ed.): Resilience for Today: Gaining Strength from Adversity. United States of America: Greenwood Publishing Group, Inc, pp. 1-29.

Gustafson B 1999. Health-care. Financ Manag, 53(7): 64-66.

Higgs M 2004. A study of the relationship between emotional intelligence and performance in UK call centres. J Manag Psychol, 19(4): 442-454.

Hjemdal O, Friborg O, Stiles TC, Martinussen M, Rosenvinge JH 2006. A new scale for adolescent resilience: Grasping the central protective resources behind healthy development. Measure Eval Counsel Dev, 39: 84-96.

Hochwälder J 2006. An empirical exploration of the effect of personality on general and job-related mental ill health. Soc Behav Pers Int J, 34: 10511070.

Holdsworth L, Cartwright S 2003. Empowerment, stress and satisfaction: An exploratory study of a call centre. Leader Organ Develop J, 24(3): 131140.

Holman D 2004. Employee well-being in call centres. In: S Deery, N Kinnie (Eds.): Call Centres and Human Resource Management: A Cross-national Perspective. New York: Palgrave Macmillan, pp. 223-245.

Jaffe-Gill E, Smith M, Larson H, Segal J 2007. Understanding Stress: Signs, Symptoms, Causes and Effects. From< http://www.helpguide.org/mental/ stress signs.htm> (Retrieved April 22, 2008).

Jensen SA 2008. Relationship between Personality Type and Job Burnout among Special Education Teachers. Dissertation Abstracts International.

Johnson L, Wiechelt SA 2004. Introduction to the special issue on resilience. Substance Use and Misuse, 39: 657-670.

Johnson MO, Howard S 2002. Quantifying and evaluating resilience-promoting factors: Teacher's beliefs and perceived roles. Res Edu, 70: 50-64.

Kim HJ, Shin KH, Unbreit WT 2000. Hotel job burnout: The role of personality characteristics. Int $J$ Hospit Manag, 26(2): 421-434.

Kokkinos CM 2007. Job stressors, personality and burnout in primary school teachers. $\mathrm{Br} \mathrm{J} \mathrm{Am} \mathrm{Col}$ Health, 55: 239-245.
Korotkov D 2008. Does personality moderate the relationship between stress and health behaviour? Expanding the nomological network of the Fivefactor Model. J Res Pers, 42(6): 1418-1426.

Kruger L, Prinsloo H 2008. The appraisal and enhancement of resilience modalities in middle adolescents within the school context. S Afr J Edu, 28: 241-259.

Langelaan S, Bakker AB, Van Doornen LJP, Schaufeli WB 2006. Burnout and work engagement: Do individual differences make a difference? Pers Indiv Differ, 40: 521-532.

LePine JA, LePine M, Jackson CL 2004. Challenge and hindrance stress: Relationships with exhaustion, motivation to learn, and learning performance. J Appl Psychol, 89: 883-891.

Lew CC 2001. A Factor Analytical Study of Adult Career Concerns, Career Status and Career Resilience. Dissertation, Unpublished. Rand Afrikaans University, South Africa.

Lewig KA, Dollard MF 2003. Emotional dissonance, emotional exhaustion and job satisfaction in call centre workers. Eur J Work Organ Psychol, 12: 366-392.

Lim BC, Ployhart RE 2006. Assessing The Convergent and Discriminant Validity of Goldberg's International Personality Item Pool: A Multitrait-Multimethod Examination. Organ Res Meth, 9(1): 29-54. From< http://orm.sagepub.com/cgi/content/abstract/9/1/29> (Retrieved October 01, 2009).

London M 1993. Relationships between career motivation, empowerment and support for career development. J Occup Organ Psychol, 66: 55-69.

Luthans F, Norman SM, Avolio BJ, Avey JB 2008. The mediating role of psychological capital in the supportive organizational climate-employee performance relationship. J Organ Behav, 29: 219238.

Luthens F, Avolio B, Avery J, Norman S 2007. Psychological capital: Measurement and relationship with performance and satisfaction. Person Psychol, 60: $541-572$.

Malhotra N, Mukherjee A 2004. The relative influence of organisational commitment and job satisfaction on service quality of customer contact employees in banking call centres. J Serv Market, 18(3): 162-174.

Mandleco BL, Peery JC 2000. An organizational framework for conceptualizing resilience in children. $J$ Child Adolesc Psychiatr Nurs, 13(3): 99-111.

Martin B 2006. Stress and Personality. From< http:// psychcentral.com/lib/2006/stress-and-personality/> (Retrieved July 02, 2008).

Maru M 2002. Job Burnout: A Review of Recent Literature. J Occup Organ Psychol, 106(1): 5-48. From< http://ajol.info/index.php/ajpsy/article/ view/30282/30493> (Retrieved September 22, 2008).

Maslach C 1982. Burnout: The Cost of Caring. Englewood Cliffs, NJ: Prentice Hall.

Maslach C 1986. Stress, burnout and the workaholic syndrome. In: R Kilburg, R Thoreson, P Nathan (Eds.): Professionals in Distress: Issues, Syndromes and Solutions in Psychology. Washing- 
ton, DC: American Psychological Association, pp. 53-75.

Maslach C, Jackson SE 1986. Maslach Burnout Inventory: Manual. 2nd Edition. Palo Alto, CA: Consulting Psychologists Press.

Maslach C, Jackson SE, Leiter MP 1996. Maslach Burnout Inventory: Manual. $3^{\text {rd }}$ Edition. Mountain View, California: Consulting Psychologists Press.

Maslach C, Leiter MP 1997. The Truth about Burnout: How Organizations Cause Personal Stress and What To Do About It. San Francisco, CA: JosseyBass Inc.

Maslach C, Schaufeli WB, Leiter MP 2001. Job burnout. Annu Rev Psychol, 52: 397-422.

McCrae RR, Costa PT 1989. Reinterpreting the Myers-Briggs Type Indicator from the perspective of the Five-factor Model of personality. J Pers, 57(1): 17-40.

McCrae RR, Costa PT 2006. Personality in Adulthood: A Five-factor Theory Perspective. $2^{\text {nd }}$ Edition. New York: Guilford Press.

McCrea RR, John OP 1992. An introduction to the Five-factor Model and its applications. J Pers, 60(2): $175-215$

Miller ED 2003. Reconceptualising the role or resiliency in coping and therapy. $J$ Loss Trau, 8: 239246.

Miner MH 2007. Burnout in the first year of ministry: Personality and belief style as important predictors. Ment Health Relig Cult, 10: 17-29.

Morgan B, De Bruin K 2010. The relationship between the Big Five Personality traits and burnout in South African university students. S Afr J Psychol, 40(2): 182-191.

Morris CG, Maisto AA 2002. Psychology: An Introduction. $11^{\text {th }}$ Edition. New Jersey: Pearson Education, Inc.

Murray G, Judd F, Jackson H, Fraser C, Komiti A, Pattison P, Robbins G 2009. Personality for free: Psychomentric properties of a public domain Australian measure of the Five-factor Model. Aust J Psychol, 61(3): 167-174.

Myers DG 2008. Exploring Psychology. $7^{\text {th }}$ Edition. New York: Worth.

Neill JT, Dias KL 2001. Adventure Education and Resilience: The Double Edged Sword. J Advent Edu Outdoor Learn, 1(2): 35-42. From <http://wilderdom. com/abstracts/NeillDias2001 Adventure Education ReslienceDoubleEdgedSword.htm> (Retrieved December 01, 2009).

Nicholas L 2003. Introduction to Psychology. Cape Town: UCT Press.

Norman WT 1963. Toward an adequate taxonomy of personality attributes: Replicated factor structure in peer nomination personality ratings. $J$ Abnorm Soc Psychol, 66: 574-583.

Norman WT 1967. 2800 Personality Trait Descriptors: Normative Operating Characteristics for a University Population. Ann Arbor: Department of Psychology, University of Michigan.

O'Neil D 2006. Personality Development. From< http:/ /anthro.palomar.edu/social/soc_3.htm> (Retrieved October 16, 2008)

O'Rourke N 2004. Psychological resilience and the well-being of widowed women. Ageing Int, 29(3): 267-280.
Ong AD, Bergeman CS 2004. Resilience and adaptation to stress in later life: Empirical perspectives and conceptual implications. Ageing Int, 29(3): 219246

Paine WS 1982. Job Stress and Burnout: Research, Theory and Intervention Perspectives. United States of America: SAGE Publications Ltd.

Pawlik-Kienlen L 2007. The Big Five Personality Traits: Your Personality Affects Every Aspect of Your Life! From< http://psychology.suite 101. com/article.cfm/the_big_five_personality traits> (Retrieved October 07, 2008).

Philippe FL, Lecours S, Beaulieu-Pelletier G 2009. Resilience and positive emotions: Examining the mediating role of emotional memories. J Pers, 77(1): 139-175.

Piedmont RL 1993. A longitudinal analysis of burnout in the health care setting: The role of personal dispositions. J Pers Assess, 61: 457-473.

Renck B, Weisæth L, Skarboè SRG 2002. Stress reactions in police officers after a disaster rescue operation. Nord J Psychiatry, 56(1): 7-14

Rothmann S 2006. Work-related Well-being: Implications for Health and Safety. Paper presented at the $5^{\text {th }}$ South African Behavioural-Based Safety Conference, Johannesburg.

Schultz D, Schultz SE 1998. Psychology and Work Today: An Introduction to Industrial and Organizational Psychology. $7^{\text {th }}$ Edition. New Jersey: Prentice-Hall, Inc.

Schutte N, Toppinnen S, Kalimo R, Schaufeli WB 2000. The factorial validity of the Maslach Burnout Inventory-General Survey (MBI-GS) across occupational groups and nations. J Occu Organ Psychol, 73: 53-67.

Scott E 2007. The Traits, Benefits and Development of Emotional Resilience. From< http://stress. about. com/od/optimismspirituality/a/optimismbenefit. htm > (Retrieved March 14, 2008).

Siebert A 2005. The Resiliency Advantage. BerrettKoehler Publishers, Inc.

Singh J 2000. Performance productivity and quality of frontline employees in service organizations. $J$ Market Res, 64(2): 15-35.

Singh J, Goolsby JR 1994. Behavioural and psychological consequences of boundary spanning burnout for customer service representative. J Market Res, 94: 558-570.

Skyrme P, Wilkinson L, Abraham JD, Morrison JD 2005. Using personality to predict outbound call centre job performance. Appl Hum Resour Manage Res, 10(2): 89-98.

Smith M, Jaffe-Gill E, Segal J, Segal R 2007. Preventing Burnout Signs, Symptoms and Strategies to Avoid it. From< http://www.helpguide.org/mental/burnout_signs_symptoms.htm\#signs> (Retrieved February 25, 2008).

Smith MK 2009. Innovation Activities in Call and Contact Centres - An Exploratory Study. Doctor of Philosophy Thesis, Unpublished. University of Strathclyde, Glasgow, United Kingdom.

Storm K, Rothmann S 2003. The relationship between burnout, personality traits and coping strategies in a corporate pharmaceutical group. S Afr J Indus Psychol, 29(4): 35-42. 
Strumpfer DJW 2003. Resilience and burnout: A stitch that could save nine. S Afr J Psychol, 33(2): 6979.

Taylor P, Bain P 1999. 'An assembly line in the head': Work and employee relations in the call centre. Indus Relat J, 30(2): 101-117.

Theron LC 2004. The role of personal protective factors in anchoring psychological resilience in adolescents with learning disabilities. $S$ Afr $J E d u$, 24(4): 317-321.

Townsend K 2007. Recruitment, training and turnover: Another call centre paradox. Person Rev, 36(3): 476-490.

Trull TJ, Deary DC 1997. Comparison of the Big Five Factor structure across samples of Chinese and American adults. J Pers Assess, 69(2): 324-341.

Tsaousis I 1999. The traits personality questionnaire (TPQue): A Greek measure for the Five Factor model. Pers Indiv Differ, 26: 271-283.

Tupes EC, Christal RC 1961. Recurrent Personality Factors Based on Traits Ratings (Tech. Rep.). Lackland Air Force Base, TX: USAF.

Tusaie K, Dyer J 2004. Resilience: A historical review of the construct. Holistic Nursing Practice, 18(1): 3-8.

Van den Berg H, Bester C, Janse-van Rensburg-Bonthuyzen E, Engelbrecht M, Hlope H, Summerton J, Smit J, du Plooy S, van Rensburg D 2006. Burnout and Compassion Fatigue in Professional Nurses. Bloemfontein: Centre for Health Systems Research and Development.
Van Dyk AC 2007. Occupational stress experienced by caregivers working in the HIV/AIDS field in South Africa. Afr J AIDS Res, 6(1): 49-66.

Visser WA 2007. Daily Hassles, Resilience and Burnout of Call Centre Staff. Philosophiae Doctor Thesis, Unpublished. Potchefstroom, South Africa: North West University.

Wagnild GM, Young HM 1993. The Resilience Scale. From< http://www.resiliencescale.com/> (Retrieved May 13, 2009)

Wallace CM, Eagleson G, Waldersee R 2000. The sacrificial HR strategy in call centres. Int J Serv Ind Manag, 11(2): 174-184.

Wharton A 2003. The affective consequences of service work: Managing emotions on the job. Work Occup, 20(2): 205-232.

Wu KD, Clark LA 2003. Relations between personality traits and self-reports of daily behaviour. J Res Pers, 37: 231-256.

Youssef CM, Luthans F 2007. Positive organizational behaviour in the workplace: The impact of hope, optimism and resilience. J Manag, 33: 774-800.

Zapf D, Isic A, Bechtoldt M, Blau P 2003. What is typical for call centre jobs? Job characteristics and service interactions in different call centres. Eur J Work Organ Psychol, 12(4): 311-340.

Zellars KL, Perrewe PL, Hochwarter WA 2000. Burnout in health care: The role of the five factors of personality. J Appl Soc Psychol, 30(8): 15701598 .

Zeng CK, Chi K 2006. Relationship of Big Five personality with employee's job burnout. Chi J Clin Psychol, 15(6): 614-616. 